\title{
Ubuntuism and Africa: Actualised, Misappropriated, Endangered, and Reappraised $^{1}$
}

\section{Francis B. Nyamnjoh \\ ORCID iD: https://orcid.org/0000-0002-4702-8874}

\begin{abstract}
The idea that human beings are bound to each other inextricably is at the heart of this lecture about African agency. It draws on the African philosophy Ubuntu, with its roots in human incompleteness, sociability and inclusivity. Ubuntu's precepts and workings are severely tested in these times of rapid change, accelerated nimblefootedness, and multiple responsibilities. Africans negotiate their social existence between urban and rural life, continental and transcontinental realities, and all the market forces that influence relationships and loyalties. Between ideal and reality, dreams and schemes, how is Ubuntu actualised, misappropriated, and endangered? This talk unearths the intrigues and contradictions that go with inclusivity in Africa. Basing my argument on the ideals of trust, conviviality and support embodied in the concept of Ubuntu, I seek to demonstrate how the pursuit of personal success and even selfaggrandisement challenges these ideals, thus leading to discord in social relationships. Even as it is increasingly seriously tested by opportunism, Ubuntuism, sometimes a reality and sometimes an ideal, brings hope and redemption, and offers a feasible framework for participatory and inclusive emancipatory social change.
\end{abstract}

Keywords: Ubuntuism, identity, opportunity, African migrants, people left behind

${ }^{1}$ This article was first prepared and presented as a paper at the Africa Day Memorial Lecture, Auditorium, Equitas Building, University of the Free State, Bloemfontein, Wednesday 22 May 2019 at 17:30. 


\section{Introduction: Ubuntu}

In this Africa Day Memorial Lecture, I seek to give currency to concepts such as African communitarianism, Ubuntu, Africanness, Afrocentricity, Afrocentrism, Africanity, Afrikology, humanness, wholeness, and reciprocal altruism. Like Pan-Africanism and the concept of African Renaissance, such apparently collectivist pretensions are suggestive of the potential in seeing and articulating identity making and belonging as flexible, inclusive, dynamic, and complex aspirations and processes. Similar to the unity, solidarities and relevance craved, the micro and macro level importance of these identities in the making are abstract and grounded, local and global, simultaneously. They are far less about single identities than about offering mental and fantasy spaces for disparate identities to aspire to inspire co-existence in freedom and dignity.

Inclusivity is an established theme in popular culture in Africa, from song lyrics to home entertainment videos, television series, drama sketches on radio, and novel narratives. Collective success is emphasised, and individuals may not begin to consider themselves to have succeeded unless they can demonstrate the extent to which they have included intimate and even distant others actively: family members and friends, fellow villagers, and even fellow nationals, depending on one's stature and networks. Elsewhere millionaires and billionaires are men and women with tangible personal assets to substantiate their claims to riches. The logic of collective success in many an African circle means no one can truly be considered successful, if they have not involved themselves in ad infinitum redistribution of their accumulations, spreading them broadly and deeply (Nyamnjoh and Rowlands 1998; Nyamnjoh 2002; 2011; 2013; 2015). The world views, cultural traditions, and practices that inform such investment in interconnections, interdependences, and inclusivity, draw from and promote philosophies of personhood, being, becoming, and belonging, as a permanent work in progress, in recognition of incompleteness as a normal order of things and beings (Nyamnjoh 2017, 2018).

Ubuntu is an Nguni word, widely used in South Africa by Zulu, Xhosa, Swati, and Ndebele peoples, and increasingly adopted by other groups within the country and across Africa and the world. Among isiXhosa speaking South Africans, the expression is usually Ubuntu ungamuntu ngabanye abantu, translated roughly as 'people are people through other people'. The singular of which is umntu ngumntu ngabantu: 'a person is a person through other people' or 'a human being is a human being because of other human beings' (Letseke 2012: 48). More colloquially, 'I am because you are' or 'We are together'. It 
should be added, however, that it is not enough to recognise and be conscious of togetherness to fulfil Ubuntu. There is need for collective social action that ensures genuine participation and inclusivity for all and sundry. As a philosophy of life, Ubuntu 'espouses a fundamental respect in the rights of others, as well as a deep allegiance to the collective identity' (Mabovula 2011: 40), through compassion, interconnectedness, interdependence, and deeprootedness in community. Ubuntu encourages a definition and understanding of individuals 'primarily through their relationships with others rather than by their status as discrete individuals' (Whitworth \& Wilkinson 2013: 121).

This philosophy of incompleteness and of self-activation through relationships of interdependence, shared throughout most of the African continent (not necessarily using the same terminology), 'regulates the exercise of individual rights by emphasising sharing and co-responsibility and the mutual enjoyment of rights by all' (Mabovula 2011: 40). It posits that humans are 'related to and depending on each other' and 'are responsible for ensuring that others have everything that they need' (Whitworth \& Wilkinson 2013: $125)$.

According to Desmond Tutu - whose articulations on Ubuntu as resilience and fortitude through forgiveness were at the heart of the South African Truth and Reconciliation Commission process (Bell 2002: 85-107) one has Ubuntu (' $\mathrm{Yu}, \mathrm{u}$ nobuntu') when one is 'generous, hospitable, friendly, caring and compassionate'. Ubuntu is sharing what one has, and acknowledging and providing for the fact that one's 'humanity is caught up, is inextricably bound up' with the humanity of others - hence the affirmation: "a person is a person through other people", "I am human because I belong", and I am 'diminished when others are humiliated or diminished' (Tutu 1999: 34-35). To Tutu, Ubuntu 'has to do with what it means to be truly human, to know that you are bound up with others in the bundle of life' (Tutu 2004: 26).

In a speech at a memorial service organised in Soweto in December 2013 in honour of Nelson Mandela, then US President Barack Obama described the late Mandela as an embodiment of Ubuntu. To Obama, Mandela taught millions to find the truth of Ubuntu within themselves. He recognised that 'we are all bound together in ways that can be invisible to the eye; that there is a oneness to humanity; that we achieve ourselves by sharing ourselves with others, and caring for those around us'; and that we need to trust in order to be trusted by others. Mandela taught us that 'reconciliation is not a matter 
of ignoring a cruel past, but a means of confronting it with inclusion, generosity and truth ${ }^{2}$.

\section{Ubuntuism in Practice and Perspective}

Ubuntu can be considered as a social organising principle at the heart of which is the humility of incompleteness (Nyamnjoh 2017, 2018). It could inspire stable relationships in the communities in which it is practised by encouraging individuals to recognise the interconnections that make their sociality possible and to 'learn how to create mutual interests, giving mutual satisfaction'. Ubuntu seeks to socialise those who embrace it to recognise the virtues of giving, receiving, and giving in turn. It is a deterrent to what Mauss terms 'The brutish pursuit of individual ends', which is 'harmful to the ends and the peace of all [...] and rebounds on the individual himself' (Mauss 1990[1950]: 8277).

By encouraging the circulation of things, Ubuntu provides a framework for happiness through selfless giving (Agamben 2013), one where poverty and wealth are constantly on the move, changing hands and changing places, ensuring that everyone shall have his fair share of opportunity and possibility - of sunshine, rainfall, windfall, pitfall and downfall - in life. Ubuntu's subscription to interconnection and interdependence is a refusal to confine some from birth to a fate worse than death when too many things are in too few hands and mutual obligations downplayed. The notion of Ubuntu and its ethic of caring, sharing and considerateness are not uniquely African, even if African civilisations are understood widely to be governed by its philosophy.

What, in the everyday lives of those implicated, does it mean to live out the claim that a person is a person because of others? In other words, what are the challenges, and how are these challenges negotiated, to ensure fulfil-

${ }^{2}$ See The White House Office of the Press Secretary, 'Remarks of President Barack Obama - As Prepared for Delivery Remembering Nelson Mandela, Johannesburg, South Africa 10 December 2013', www.whitehouse.gov/thepress-office/2013/12/10/remarks-president-barack-obama-prepared-delivery, accessed on 24 July 2015;

see also $w$ ww. youtube.com/watch? $=4 \mathrm{vUB} 363 \mathrm{cRqE} \&$ spfreload=10, accessed on 24 July 2015. 
ment of the maxim that 'to be a human being is to affirm one's humanity by recognising the humanity of others and, on that basis, establish humane relations with them' (Ramose 1999: 52)?

The Ubuntu suggestion that 'humans depend completely on one another for their development' (Christians 2004: 244) is similar to Mauss' notion of 'the gift', which encourages a life of mutuality, obligation, and reciprocity and emphasises a continuous act of sharing, to maintain a balance of reciprocity between oneself and others. The obligatory circulation of wealth entails an obligation to reciprocate and to make oneself available to others in ways that allow for the maintenance of the giving and receiving cycle (Mauss 1990[1950]: 8-18). As Mauss puts it, 'To refuse to give, to fail to invite, just as to refuse to accept, is tantamount to declaring war; it is to reject the bond of alliance and commonality' (Mauss 1990[1950]: 13).

A truly rich person, quite paradoxically, is someone engaged in an ongoing process of material impoverishment, someone constantly reaching out to involve others in their material possibilities and promise. A gift from them to others is a gift not just in material terms but an extension of themselves. Giving abundantly enriches them abundantly. Through sharing, they activate and maintain relationships. Marcel Mauss calls this 'an intermingling'. 'Souls are mixed with things; things with souls'. 'Lives are mingled together' (Mauss 1990 [1950]: 20).

Fortune in itself can never really substitute the ultimate gift of all - the gift of oneself, one's soul or one's essence - because things are only a substitute or proxy for the gift of self - which is what others really desire and appreciate.

This idea of gifts and giving is very prominent in many religions. In Christianity for example, the Bible urges self-abnegation through selflessness in giving, promising salvation for humility and making a virtue of poverty: Matthew 5: 42 - 'Give to the one who asks you and do not turn away from the one who wants to borrow from you'; Proverbs 19: 17 - 'The one who is gracious to the poor lends to the Lord, and the Lord will repay him for his good deed'; Proverbs 28: 27 - 'Whoever gives to the poor will lack nothing'; Corinthians 9: 7 - 'God loves a cheerful giver'.

In many a religious circle, happiness is considered a reward for selfless giving. In Catholicism for instance, monastic orders and convents emphasise asceticism and monks and reverend sisters are expected to exemplify the beatitudes reserved for 'the poor in spirit', 'the meek', 'those who hunger and 


\section{Francis B. Nyamnjoh}

thirst for righteousness', 'the pure in heart', and 'those who are persecuted because of righteousness' (Matthew 5: 3). For, in the words of Jesus Christ, 'It is easier for a camel to go through the eye of a needle than for a rich person to enter the Kingdom of God!' (Matthew 19: 24).

The very same rigorous self-denial and active self-restraint are encouraged in Protestant Christianity as well. Fulfilment comes from singleminded religious devotion to honest, productive, hard work, and not from the pursuit of wealth and worldly possessions, which is not to deny the rise and proliferation of Charismatic Pentecostal Christianity that preaches prosperity through worldly wealth. In a sense, poverty and abnegation could be perceived as a technology of self-edification through self-abnegation aimed at ensuring that individuals are able to attain 'a certain state of happiness, purity, wisdom, perfection, or immortality' (Foucault 1988: 18) comparable to the beatitudes of Heaven. Seen in this light, it is easy to understand the degree to which personal riches can be an embarrassment, a curse, an encumbrance, or a crown of thorns, especially when the rich person fails to ensure circulation by passing the riches onto others, needy or not.

Gifts postpone the ultimate sacrifice, enabling the giver to live. Like Abraham in the Bible who sacrificed a ram so Isaac might live. The more personal the gift and the more history it has accumulated, the more likely it is to be accepted as a substitute, double, or lookalike, of the gift-giver by the receiver. David Graeber (2001) argues that because money is too generic to accumulate history, it cannot add to the holder's identity in the same manner that other things can. Because of its ephemeral, here-and-now character, money, paradoxical as it might seem, lacks the social-marker capacity to activate the receiver to the same degree of potency required for social visibility as would a more personal thing that has accumulated history or that is capable of such history. Few are able to harness money (personalise and give it the beginnings of a history) through conversion into things of greater value before it evaporates like petrol, sending the exasperated receiver back to the giver to ask for more, in Oliver Twist-like fashion. As a gift, money is like a snack that seldom satisfies hunger.

Ultimately, being human is all about debt and indebtedness. It is about the need to recognise and provide for the fact that life is all about the circulation of debt - that it is important to recognise the reality of one's eternal indebtedness to others - be these fellow humans, the natural environment and its resources, or the supernatural forces and one's ancestors and forebears. 
Debt embodies the essence of morality and informs everything we do (Graeber 2011: 89-126) ${ }^{3}$. In contexts of sociality where a person invariably leans on others to achieve something, the sentiment of one good turn deserves another is common currency. Even if a person is not in debt financially or materially, they might owe debts of gratitude. Whatever the case, individuals are beholden to a frame of reference that does not accommodate overly personal and self-interested forms of success as an end. This could well be the reason, over and above, as a means of escaping taxation. Why even in contexts of entrenched capitalism, many a billionaire or millionaire tends to start a foundation and engage in philanthropy. A truly wealthy person is someone with little or nothing to show for their sweat and toil, not because he or she is lazy, has failed to make it in life, or has been the victim of a devaluation of the local currency, but because they have, willingly or reluctantly, sacrificed their 'wealth-in-things' for 'wealth-in-people' (Guyer \& Belinga 1995).

\section{Ubuntuism and the Seesaw of Opportunity and Opportunism}

Ubuntuism is an invitation to accept and embrace that no humanity is complete if it entails wasting away the humanity of others, however justifiable that might seem in the short term. When are claims of Ubuntuism an opportunity for collective success and social inclusivity, and when are they a mere ploy for opportunism? An individual toiling away in a distant land might be a victim of various claims by family, friends, and acquaintances who are not themselves ready to reciprocate when the individual comes knocking with claims and demands of their own. How then does one differentiate opportunity from opportunism? When should relationship claims be taken seriously, and when should they be ignored?

To the Nigerian actor and comedian, Nkem Owoh, one should be beware of those who come claiming relationships only when one's circumstances have improved. He addresses this in his song 'Know Me When I'm Poor' ${ }^{4}$. It is when a person is poor that he knows those who care clearly about him.

${ }^{3}$ See also David Graeber, 'The Moral Power of Debt'. www.bbc.co.uk/programmes/b05447pc, accessed on 27 May 2015. ${ }^{4}$ www.youtube.com/watch?v=z0JGB0PV0mE, accessed on 9 March 2014. 
I'd like to explore with you examples of opportunities and opportunisms within Ubuntuism.

\section{Tensions between African Migrants and Families and Friends Left Behind}

The capitalist economy and increasing globalisation have brought about even greater nimblefootedness among Africans compelled to seek ever greener pastures away from their home villages, hometowns, home cities, and even countries and home continents. Family and friends left behind by Africans migrating from their villages, towns, cities and countries, look for ever more creative ways and means to extend themselves and their arms to keep track of the kin and friends and ensure that the successes of kin and friends are extended constantly to include them.

It is against this background that I invite you to explore with me some of the tensions between African migrants and families and friends left behind. To every story of disappointment and the opportunism in claims and denials of Ubuntu, there are counter stories of the solidarity, mutuality, and collective responsibility that have developed through migrants responding to the obligation to share their wealth, however hard earned, with the community of family and friends left behind. Studies of development associations comprised of sons and daughters of particular villages, ethnicities, or regions in town or abroad, targeting the needs and needy of various home villages across the continent, reveal these instances of opportunity and of opportunism.

There are cases in which remittances have sustained families in myriad ways. However, even when migrants bend over backwards to redistribute their wealth with parents and other relations back in the home country and village, it is not always guaranteed that their efforts are appreciated.

Honorine Express is a US-based Cameroonian migrant renowned for her YouTube videos castigating opportunistic relationships between diaspora Cameroonians and family and friends back in Cameroon. Her posting titled 'Demanding and ungrateful family members' captures the intricacies of relentless demands by family members ${ }^{5}$.

5 Honorine Express, 'Demanding and Ungrateful Family Members', www.youtube.com/watch?v=OJ3wZ97Ab0w, accessed on 07 August 2015. 
In December 2018, I participated in a panel discussion at the Royal Netherlands Academy of Science on the commodification of football and the exploitation of African footballers in Europe by their clubs and agents. Many an African footballer in Europe would argue that such exploitation is also by families and friends back home in Africa.

A story that resonates with issues raised by Honorine Express in her video postings is the one of renowned Togolese international footballer Emmanuel Adebayor. He has played for several top European clubs, including Monaco, Arsenal, Manchester City, and Tottenham Hotspurs.

On 6 May 2015, I accessed a detailed Facebook posting in English and French $^{6}$ in which he complained about the catalogue of ingratitudes that his Togolese family had shown him repeatedly, despite his generosity in their regard. He explains that his finally coming out in the open with the story has less to do with 'money' and more with the hope that 'all families can learn from what happened in mine'.

Adebayor recounts how at the age of 17 , he built a house for his family with his first wages as a footballer. This was to ensure that his family was safe. When he was awarded the trophy for African Player of the Year in 2008, he took his mother along with him to share the honour and 'to thank her for everything'. That same year, he 'brought her to London for various medical check-ups', but when his daughter was born and he called his mother to announce the birth, the mother did not want to hear about it, because 'she immediately hung up the phone'.

Despite their differences, he continued to support his mother. He sponsored her travel to Lagos to meet with Nigerian Prophet T. B. Joshua. He also gave her 'a great amount of money to start a business' and allowed her to put his name and picture on the items she sold for publicity. Faced with his mother's lack of appreciation, he asks: 'What else can a son do in his power to support his family?'

Doing even more does not seem to bring recognition and gratitude in his case. He bought a 15-room house in East Lagos, Ghana, for \$1.2 million and found it normal to let his older sister, Yabo, and half-brother, Daniel, stay in the house. When he decided to go to the house on vacation a few months

${ }^{6}$ See,

www.facebook.com/permalink.php?story_fbid=1650071258554893\&id=137 7345199160835\&substory_index=0, accessed on 06 May 2015. 


\section{Francis B. Nyamnjoh}

later, he was surprised to see many cars in the driveway and to discover that his sister had decided to rent out the house without informing him. She had also kicked Daniel out of the house. 'When I called her and asked for an explanation, she took about 30 minutes to abuse and insult me over the phone', accusing him of being ungrateful. 'I called my mother to explain the situation and she did the same as my sister'.

Being accused of ingratitude by those he cared about was beyond his comprehension.

Kola, his brother who had lived in Germany for 25 years, was equally disappointing. Adebayor had 'fully cover[ed] the cost of his children's education' and borne the cost of several of Kola's trips back home. He had provided Kola with 'money to start a business' when Adebayor was playing his football at Monaco, but Kola had run the business to the ground quickly. What Adebayor detested the most about Kola was the lack of solidarity and compassion. This was the case when he sent Kola to bury his late brother, Peter, who passed away on July 22, 2013. 'When our brother Peter passed away, I sent Kola a great amount of money so he could fly back home. He never showed up at the burial'. Instead, he turned around and accused Adebayor of having killed Peter.

Adebayor was particularly perplexed by accusations that he did little to save Peter. He recollects how he had to drive the fastest he could from Ghana to Togo when he got news that Peter was seriously ill, only to be denied access to him by his mother who insisted that Adebayor 'should just give the money and she would solve everything', which he did. Although Kola neither contributed to nor was present at Peter's funeral, he accused Adebayor of causing Peter's death, and of having opened a shop for Peter that was 'not good enough'. Adebayor describes Kola as 'never satisfied', even though as 'a big brother' Kola 'is supposed to be doing all that I am doing for the family'. Instead, Kola keeps texting to threaten Adebayor that he would destroy his football career ${ }^{7}$. How? Kola 'told inaccurate stories about our family to The Sun in order to take some money' and sent a letter to Adebayor's club when the latter was in Madrid 'so I could get fired'.

7

www.facebook.com/permalink.php?story_fbid=1656411337920885\&id=137 7345199160835\&substory_index=0, accessed on Friday 22 May 2015. 
Adebayor is adamant that he gave Peter a decent burial, even in his absence. He recounts his father's passing thus:

On April 22nd 2005, we received some bad news. I received a call and they announced that my father passed away. I was devastated. I called my big brother and told him that we all have to be there. Again, I made sure there was a flight ticket ready for him. We all went back home and I took care of everything. A long time before my dad died, he was in the hospital one day and he asked me to make sure his funeral is not a moment of sadness. He wanted us to celebrate his life. I leave it to God to decide if the funeral I organised for my dad was what he wanted. The man who calls himself the 'big man' in the family did not contribute to anything. But he still has the boldness to say I do not take care of this family ${ }^{8}$.

Adebayor forgave a lot of hostility from Kola, including when the latter held a knife to his throat, demanding money to start a car business 9 . Adebayor repeatedly reminded himself that 'blood is thicker than water'.

Adebayor does not seem to be lucky with his family. Even his brother Rotimi, whom he sponsored into a football academy in France, resorted to stealing the phones of other players - 'Within a few months; out of 27 players, he stole 21 phones'. He went on to steal jerseys of renowned players.

Rotimi repeatedly benefitted from Emmanuel's recognition that 'blood is thicker than water'. But Rotimi would not give up stealing and abusing the privileges of 'I am your brother'. He would not apply himself as much as he was expected to with the chances he got. Emmanuel authenticates this with the following example:

One day, my mom called me early in the morning when I was still in bed. She told me that Rotimi has got a visa to go to Dubai so he can

8

www.facebook.com/permalink.php?story_fbid=1656411337920885\&id=137 7345199160835\&substory_index=0, accessed on Friday 22 May 2015.

www.facebook.com/permalink.php?story_fbid=1656411337920885\&id=137 7345199160835\&substory_index $=0$, accessed on Friday 22 May 2015. 
play football out there. He had to leave that day with his friend Kodjovi who was in the same situation. It was either they went that day or the visa would be suspended. I asked one of my guys at the time to go find tickets for my brother and his friend. We could not find any economy class ticket on that day so I had to get them both first class tickets. After all, it was an opportunity for him to make his own career in Dubai. Only 4 days later, Rotimi went back home. He explained how the lifestyle in Dubai was not made for him. He said he wasn't free to do what he wanted to do because it is a strictly Muslim place. He couldn't drink, party as much as he wanted or kiss girls in public.

When in 2005 Adebayor organised a meeting 'to solve our family issues', his entire family was of the opinion that 'I should build each family member a house and give each of them a monthly wage'. It seems Emmanuel Adebayor is seen and related to by the rest of his family as a wallet on legs. They do not relent in asking him to redistribute his wealth to them and are hostile vehemently to any idea of him expanding the pool of those he helps. 'Every time I try to help the people in need, they had to question me and all of them thought it was a bad idea'. To conclude, 'Today I am still alive and they have already shared all my goods, just in case I die' 10 .

There is little in the attitude and behaviour of his family to suggest that Emmanuel Adebayor owns himself, let alone his wealth. It is normal in claims of Ubuntu to assume that one's fortunes or riches do not belong to one alone, that one has the duty to share one's success with others - both intimate and distant. In the case of Emmanuel Adebayor, his family does not even appear to expect him to claim any of his hard-earned riches. They treat him like a hen that lays golden eggs and that is strictly forbidden from claiming any egg for itself. In the eyes of his family, however much of his riches he shares with them, he is expected to share even more - to give away until there is nothing left to give. Only then would he be forgiven and forgotten by them. After

\footnotetext{
${ }^{10}$ The full Facebook text in French as posted by Emmanuel Adebayor at these links:

www.facebook.com/permalink.php?story_fbid=1650071258554893\&id=137 7345199160835\&substory_index $=0$

www.facebook.com/permalink.php?story_fbid=1651703141725038\&id=137 7345199160835\&substory_index $=0$
} 
usurping his wealth, they would have usurped him completely - mind, body and soul - leaving him truly dead to them.

Despite not having been to school, Emmanuel Adebayor is proud of his achievements, and especially of what he did for his family, ungrateful though they are. Every now and again, he feels like committing suicide, because of the family pressures. 'For everyone who knows me, I'd do anything for my country and my people', he concludes his story ${ }^{11}$.

In three Facebook posts, Emmanuel Adebayor shares with us not only a story of how he went from humble beginnings to fame as a footballer, but more importantly, the selfless generosity with which he greeted his good fortune. As Antoinette Muller puts it in a commentary titled 'Stranger in a Strange Land: Adebayor's Silent Struggles', Emmanuel Adebayor has 'gone from having no football boots to earning enough to provide, not only for himself, but for his family, and be in a position to support a number of charity projects across Africa', and 'his actions mostly suggest that he is a good egg, who cares deeply for his fellow humans' 12 .

Adebayor's story is more common than many reading his Facebook postings might imagine.

Adebayor's story raises some perplexing questions. What could have provoked a renowned international footballer of his calibre to the point of washing his family linen on Facebook? Is his intention limited to what he claims - so that 'all families could learn from what happened'? Could this also be a way of loosening his daughter from the entrapment imposed by his insatiable family members?

Adebayor portrays himself as an excellent example of an inclusive achiever through selfless contributions to others and their welfare. He would like to redistribute what he accumulates beyond the narrow confines of his immediate family, if only they disentangle themselves from insisting on the lion's share. This is evident particularly with his brother Kola, who used kinship unashamedly and repeatedly to guilt trip and demand money from him.

11

www.facebook.com/permalink.php?story_fbid=1656411337920885\&id=137 7345199160835\&substory_index=0, accessed on Friday 22 May 2015.

Antoinette Muller, www.dailymaverick.co.za/article/2015-05-22-strangerin-a-strange-land-adebayors-silent-struggles/\#.VV7gxUYe4TY, accessed on 25 May 2015. 


\section{Francis B. Nyamnjoh}

Family members actively discouraged any attempt to spread the wealth to help other people. They would rather his Ubuntu start and end with them.

The fact that the story is told entirely from Adebayor's perspective the perspective of the hunted and not the hunter - begs the questions: Why, given his stature and prominence, did Adebayor yield to this predatory dimension of his family? He could have argued easily, as some purportedly self-made others would, that it was within his right as an individual who had made it big to seek to protect his hard earned wealth. Why did he not take this step? Is it enough to explain his position simply in terms of 'blood being thicker than water'?

Adebayor's story reveals a special bond with his father, particularly during his father's last days before passing away. Could this special bond have affected his relationship with the rest of the family? Did the rest of the family feel somehow cheated out of their share of their father's blessings by Adebayor as a result of this special bond? Could ingratitude in his regard by the family members partly be understood as claiming by force their share of Ubuntu in the form of their father's blessings? Is it possible that his father might have grown to like him more because of his success? Was it in part in guilt for the special bond between them that Adebayor accepted, literally, the request by his dying father to take care of the family?

It is also possible that Adebayor interpreted the request of his father as a call to reproduce his father by giving birth to the next generation of Adebayor's. Interpreted thus, he could easily have pointed to his daughter as evidence of having fulfilled that obligation.

By seeking to take care of the family beyond mere reproduction of his father through birth, and by accommodating his family members even in their excesses, Adebayor makes a compelling case for inclusiveness, considerateness, generosity, and humaneness, not dissimilar to the case made by Nelson Mandela for Ubuntu to which we alluded in the beginning.

\section{Conclusion: Reflections on the Future of Ubuntuism}

Ubuntuism is neither fixed nor claimed nor practised homogenously across Africa. In some countries such as South Africa it is an ideal to be recuperated, resurrected, or rediscovered through conscious acts of creative imagination and practice. Such resurrection could mobilise Ubuntuism's emancipatory potential, as a critique of and complement to Western modernity by bringing 
the latter into systematic and sustained conversations with indogenous African value systems and philosophies of personhood corrupted by colonialism, apartheid, and neoliberal individualism. The recuperation of Ubuntu is urgent, given surging economic downturns and ever diminishing possibilities for the rights and entitlements promised all and sundry under the post-apartheid constitution, which constitution, paradoxically, does not give Ubuntu the centrality it deserves.

How do Africans who travel out of their communities in quest of greener pastures and those they leave behind forge a common future? How should they join forces to demand that Europe and the West by extension assume their obligations towards a continent systematically dispossessed throughout histories of unequal encounters and unreciprocated generosity? Let us consider remittances.

The interconnections between gift and market economies materialise in the lives of African migrants and the relationships they seek to maintain with their home countries. Africans in the diaspora remit significant amounts of money to the continent yearly.

They are superexploited by the opportunism of families and friends back home, and also by companies such as Western Union and MoneyGram, which thrive on weak competition, concentration of market power, and weak financial regulation, to charge exorbitantly for remitting to Africa. Paul Collier asserts that the flow of remittances can be regarded as 'an inadvertent aid program to host countries' from the countries of origin of the migrants in question (Collier 2013: 226).

Many African migrants are very careful about how and to whom they remit and follow up on their investments judiciously, and many have fallen prey to the sort of opportunism described by Emmanuel Adebayor. Increasingly, however, Africans abroad and in general are wising up to the tricks of family and friends. Notwithstanding such alertness, it is hardly correct to blame the opportunism of relations and friends back home entirely on the waywardness and unethical behaviour of the individuals involved. Structural factors informing growing global inequalities and the tendency to privilege the market over all other forms of economy play an important role in determining relationships of opportunity and opportunism - at global and local levels, by individuals, states, and corporations, among other actors. And so does history as a technology of domination and control.

Adebayor's negative experience explains in part why remittances by 
African migrants abroad have a 'significant positive impact on income inequalities in African countries' (Anyangwu 2011), even when the fact of remitting does not necessarily achieve the envisaged outcome for those doing the remitting (Collier 2013: 206-213). Remittances, it has been noted, also contribute significantly to economic growth in Africa (Lartey 2013), with Singh et al. (2010: 312) suggesting that 'countries with well-functioning domestic institutions' appear to 'be better at unlocking the potential for remittances to contribute to faster economic growth'.

As the popular term 'black tax' suggests, remittances is a form of taxation, even if not by the state, but directly by family and friends who feel entitled to partake of the personal success of migrants (Manqoyi 2018). Like with other forms of taxes - if social media commentary berating relatives and friends for constantly insisting on compliance willy-nilly are anything to go by - those who pay black tax are not always enthusiastic about doing so.

Stories such as the one of Adebayor provide a moral lens through which to understand the opportunism of Ubuntu. Individuals caught betwixt cultures and continents navigate market and gift economies to express their connectedness and humanity. Surging opportunism and the corruption of Ubuntu that comes with it are a clarion call to rediscover, reinvent, and reinvest in the interconnections and interdependencies between market and gift economies, obligation and reciprocity, autonomy, and sociability. Put differently, opportunism out-of-control is a clarion call to reunite the hunter and the hunted, each with the capacity to tell the story of the hunt, ever conscious as they both should be of the prospect that the hunter can be hunted and the hunted the hunter.

Humanity, human rights, and democracy cannot be considered apart from the economies and inequalities resulting from the global integration of markets that is leaving many behind. What practical prospects and possibilities are there for Ubuntuism in the twenty-first century? This is an age of crude paradoxes: incredulous wealth amidst implausible penury, phenomenal food wastage amidst mountains and valleys of hunger, and concentration of resources in the hands and homes of a few while productive resources around the world are being devastated.

Theoretically Ubuntuism would and should triumph in a context like our current world, where there is more than enough wealth to go around, more than enough resources for everyone to enjoy at least a minimal standard of living. The problem, in its simplest form, is one of equity and distribution. We 
do not use the world's resources wisely. We hoard and even destroy them. What about those excluded from their fair share of opportunity? The existential situation is absurd.

Africa might be 'poor' according to economists but is certainly not poor materially or otherwise. Africa is rich in social, cultural, conceptual, symbolic, and other forms of capital. Marketisation, monetisation, commodification, and rationalisation are not the only, nor necessarily the most important, system of value for social life. What may be considered 'poor' are systems and structures that recognise and provide for incompleteness by insisting on conviviality.

The tendency to focus overly on economic wealth, and monetary and commodity value of sociality is delusory. It creates an illusion of the omnipotence of economics - and a particular form of economics: that of the market economy. Wealth in things and a fixation on economic capital and a logic of rational choice seem rather reductive when placed alongside philosophies and practices of inclusiveness, African, or otherwise. Partaking in a cosmological epistemology of infinite possibilities of forms and transformations of being, allows one to see things in people and people in things.

I have broached the context of globalisation and histories of unequal encounters that have shaped relations in Africa and beyond under global capitalism. I have argued that, in the spirit of Ubuntu, Africans, their identities, and mobilities are part and parcel of the experience of being human in a world on the move. And their contributions are needed in today's world more than ever.

\section{References}

Agamben, G. 2013. The Highest Poverty: Monastic Rules and Form-of-Life. Stanford: Stanford University Press.

Bell, R.H. 2002. Understanding African Philosophy: A Cross-Cultural Approach to Classical and Contemporary Issues. New York: Routledge.

Christians, C.G. 2004. Ubuntu and Communitarianism in Media Ethics. Ecquid Novi 25,2: 235 - 256. https://doi.org/10.3368/ajs.25.2.235

Collier, P. 2013. Exodus: Immigration and Multiculturalism in the $21^{\text {st }}$ Century. London: Penguin Books. 
Foucault, M. 1988. Technologies of the Self. In Martin, L.H., H. Gutman \& P.H. Hutton (eds.): Technologies of the Self: A Seminar with Michel Foucault. Amherst: University of Massachusetts Press.

Graeber, D. 2001. Towards an Anthropological Theory of Value: The False Coin of Our Own Dreams. New York: Palgrave.

Graeber, D. 2011. Debt: The First 5,000 Years. New York: Melville House Publishers.

Guyer, J. \& S.M.E. Belinga 1995. Wealth in People as Wealth in Knowledge: Accumulation and Composition in Equatorial Africa. Journal of African History 26,1: 91 - 120. https://doi.org/10.1017/S0021853700026992

Lartey, E.K.K. 2013. Remittances, Investment and Growth in Sub-Saharan Africa. The Journal of International Trade and Economic Development: An International and Comparative Review 22,7: 1038 - 1058. https://doi.org/10.1080/09638199.2011.632692

Letseka, M. 2012. In Defense of Ubuntu. Studies in Philosophy of Education 31: 47-60. https://doi.org/10.1007/s11217-011-9267-2

Mabovula, N.C. 2011. The Erosion of African Communal Values: A Reappraisal of the African Ubuntu Philosophy Inkanyiso. Journal of Human and Social Sciences 3,1: 38 - 47.

https://doi.org/10.4314/ijhss.v3i1.69506

Mauss, M. [1950] 1990. The Gift: The Form and Reason for Exchange in Archaic Societies. New York: W.W. Norton.

Nyamnjoh, F.B. 2002. 'A child is one Person only in the womb': Domestication, Agency and Subjectivity in the Cameroonian Grassfields. In Werbner, R. (ed.): Postcolonial Subjectivities in Africa. London: Zed.

Nyamnjoh, F.B. 2011. Cameroonian Bushfalling: Negotiation of Identity and Belonging in Fiction and Ethnography. American Ethnologist 38,4: 701 713. https://doi.org/10.1111/j.1548-1425.2011.01331.x

Nyamnjoh, F.B. 2013. Politics of Back-Scratching in Cameroon and Beyond. In Drulák, P. \& Š. Moravcová (eds.): Non-Western Reflection on Politics. Frankfurt am Main: Peter Lang.

Nyamnjoh, F.B. 2015. C'est l'homme qui fait l'homme: Cul-de-Sac Ubuntuism in Côte d'Tvoire. Bamenda: Langaa.

https://doi.org/10.2307/j.ctvh9vxkg

Nyamnjoh, F.B. 2017. Incompleteness: Frontier Africa and the Currency of Conviviality. Journal of Asian and African Studies 52,3: 253 - 270. https://doi.org/10.1177/0021909615580867 
Nyamnjoh, F.B. 2018. Drinking from the Cosmic Gourd: How Amos Tutuola Can Change Our Minds. Bamenda: Langaa.

https://doi.org/10.2307/j.ctvh9vw76

Nyamnjoh, F.B. \& M. Rowlands 1998. Elite Associations and the Politics of Belonging in Cameroon. Africa 68,3: 320 - 337.

https://doi.org/10.2307/1161252

Ramose, M.B. 1999. African Philosophy through Ubuntu. Harare: Mond Books.

Singh, R.J., M. Haacker, K. Lee \& M. le Goff 2010. Determinants and Macroeconomic Impact of Remittances in Sub-Saharan Africa. Journal of African Economies 20,2: 312 - 340. https://doi.org/10.1093/jae/ejq039

Tutu, D. 1999. No Future Without Forgiveness. Johannesburg: London: Random House. https://doi.org/10.1111/j.1540-5842.1999.tb00012.x

Tutu, D. 2004. God Has a Dream: A Vision of Hope for Our Times. Cape Town: Double Day Publishers.

Whitworth, A. \& K. Wilkinson 2013. Tackling Child Poverty in South Africa: Implications of Ubuntu for the System of Social Grants. Development Southern Africa 30,1: 121 - 134.

https://doi.org/10.1080/0376835X.2013.756219

Francis B. Nyamnjoh Professor Anthropology University of Cape Town Cape Town francis.nyamnjoh@uct.ac.za 